Article

\title{
State Regulations and Elitisation: A Study of Civil Society Elites in Indonesia and Cambodia
}

\author{
Cornelis Lay ${ }^{1}$ and Netra Eng ${ }^{2, *}$ \\ ${ }^{1}$ Department of Politics and Government, Faculty of Social and Political Sciences, Universitas Gadjah Mada, \\ 55281 Yogyakarta, Indonesia; E-Mail: conny@ugm.ac.id \\ ${ }^{2}$ Cambodia Development Resource Institute, 12152 Phnom Penh, Cambodia; E-Mail: netra@cdri.org.kh \\ * Corresponding author
}

Submitted: 11 March 2020 | Accepted: 10 June 2020 | Published: 4 September 2020

\begin{abstract}
This article analyses how and to what extent state regulation of civil society organisations (CSOs) have resulted in elitisation, i.e., the process of obtaining elite status within and beyond civil society. This is studied in the context of emerging democracy in Indonesia and shrinking civic space in Cambodia. Combining Bourdieu's concepts of field and elite with strategic action fields, the article uses data from interviews with civil society leaders. It finds different patterns. In Indonesia, elitisation occurs through a process of CSO formalisation and bureaucratisation, with elites gaining legitimacy owing to their formal offices. As a result, competition for formal positions intensifies: This is particularly notable among national CSO leaders, who may shift their activities to the grassroots level to seek further empowerment and other capitals to legitimise their elite status, facilitate the rise of leaders in existing fields, and create pluralistic forms of elites. Regulations have also resulted in the marginalisation of non-formal elites and shifted the locus of legitimacy from activism to formalism. Meanwhile, in Cambodia, regulatory formalisation and bureaucratisation has not only reduced the space for elite competition and level of competitiveness, but also created 'most dominant actors' or 'hyper-elites' who are loyal to and support the regime and its priorities while punishing those who do not. This has resulted in a monolithic form of elites.
\end{abstract}

\section{Keywords}

Cambodia; civil society organisations; elitisation; Indonesia; state regulations

\section{Issue}

This article is part of the issue "Civil Society Elites" edited by Håkan Johansson (Lund University, Sweden) and Anders Uhlin (Lund University, Sweden).

(C) 2020 by the authors; licensee Cogitatio (Lisbon, Portugal). This article is licensed under a Creative Commons Attribution 4.0 International License (CC BY).

\section{Introduction}

This article investigates the implications of state regulations regarding civil society organisations (CSOs) for the process of elitisation, i.e., the process through which CSO leaders use their capital to attain status within and beyond civil society. This article aims to answer the question of how and to what extent CSO regulations have resulted in elitisation, taking Indonesia and Cambodia as its case studies. Indonesia represents a regime that regulates the mechanisms through which CSOs access state resources and participate in policy processes. Cambodia, meanwhile, represents a case where state regulations have only been implemented recently in an attempt to increase oversight over CSOs, which first emerged (with strong international backing) in 1993.

This article focuses on civil society elites, namely CSO leaders who receive recognition within the civil society field. This is important because elite studies have focused primarily on non-CSO actors-especially society (Migdal, 1988; Sidel, 2005), religious (Buehler, 2014), state (Robison \& Hadis, 2004) and party elites (Case, 1996) - while CSO studies have emphasised organisations (Weller, 2004), movement (Aspinall, 2005; Uhlin, 
1997) and values (Appe, Barragán, \& Telch, 2017) rather than activists or leaders themselves. Activists and organisations are often treated interchangeably, and some studies even view activists as representing organisations (Afiff \& Rachman, 2019).

This article is built upon the findings of a collaborative research project during which several studies were conducted in Indonesia and Cambodia. Three techniques have been exercised to collect primary data: formal interviews, informal conversations and participant observation in formal meetings, events and daily activities. We adopted a semi-structured interview technique, using guided conversations rather than a structured inquiry to allow ample opportunities for respondents to provide their perspectives and convey their understandings of their organisational roles as well as their extra-organisational relations. Semi-structured interviews were carried out with CSOs leaders and activists. For the Cambodian case, we have decided to pseudonymise the names of all interviewees, CSO leaders and organisations (CSOs, NGOs, and political parties) in order to guarantee their safety.

In Indonesia, field studies were conducted between October 2018 and June 2019, with data also being collected through focus group discussions involving nine elites representing five important subfields: agrarian law, human rights, religion, anti-corruption and youth. Data were honed through in-depth interviews with seven leaders in the agrarian subfield, as well as a review of internal and public documents.

In Cambodia, research was conducted between May and December 2019 with six organisations, one of which-Farmer Center, an organisation made up of farmers' networks that has both policy influence and grassroots engagement-is discussed in this article. Semistructured interviews were carried out with organisations' leaders, board members and management teams, as representatives of local organisations. In total, the fieldwork comprised of in-depth interviews in Khmer with 14 people in Phnom Penh and 12 people in Kampot Province and 12 people in Preah Vihear Province.

In Indonesia, the phenomenon of elitisation was explored within the agrarian subfield using the experiences of CSO leaders involved with the Consortium for Agrarian Reform (Konsorsium Pembaruan Agraria), a consortium of more than $150 \mathrm{CSO}$ at the national and local levels. Aside from its national scope, the Consortium for Agrarian Reform was also chosen because of its deep roots in Indonesia, having been established by elites from various CSOs.

In Cambodia, the Farmer Center was chosen as a case study, representing agriculture as a subfield that has been prioritised by the government. Established by a French CSO, the Farmer Center was chosen because it was the only CSO that was capable of transforming itself from a foreign-sponsored organisation into a national one. By 2014, it had provided direct assistance to about 160,000 families in 22 provinces. The Farmer Center fo- cuses on sharing knowledge about agricultural innovations with local farmers, farmer associations and young entrepreneurs.

This article argues that state regulations have transformed the process through which CSO leaders achieve elite status. It no longer is based on performance and individual activism; it is derived from legal status. Understanding the experiences of Indonesia and Cambodia is crucial, as regulations produce a dual process of elitisation, simultaneously expanding and contracting the spaces available for inter-elite competition. The former produces elite pluralism, while the latter produces a monopoly of elites.

The article is organised into five parts: introduction, analytical framework, state regulations and elitisation in civil society in Indonesia and Cambodia and conclusion.

\section{Field as Analytical Framework}

This article draws on Bourdieu's concept of field, which is "a field of forces structurally determined by the state of the relations of power among forms of power, or different forms of capitals...among the holders of different forms of powers" (Bourdieu, 1996, p. 264). As they involve diverse forms of capital and competition between actors, fields represent structured arenas of conflict (Swartz, 1997).

In this article, the field is understood as consisting of multiple levels. To ease discussion, this article identifies these levels as follows. First, the field refers to state society, civil society, economic society and political society. Second, the subfield refers to the civil society sectors in which actors accumulate capital and work individually or collectively. Finally, the sub-subfield refers to the CSOs in which different actors compete. Referring to Bourdieu, links between these fields are complex, and intersection is common (Wacquant, 1996, p. xi). Hence, as a theory of power, Bourdieu offers a flexible means of understanding how elites-leaders who have accumulated more capital than others-are produced and reproduced, as well as how they compete to accumulate capital and gain recognition (Bourdieu, 1990).

Furthermore, through the lens of Strategic Action Fields (SAF) - a concept derived from Bourdieu's workthe conscious activities of actors within the fields are prioritised over the unconsciousness of binary perspectives and structures. SAF looks more at actors' subjective standing than objectivity in the field (Fligstein \& McAdam, 2011). The term 'strategic action' highlights the dynamicity of the field, while still recognising its structural aspects. As such, SAF offers a meso-level social order. An order where actors interact with knowledge of one another under a set of common understandings about the purposes of the field, the relationships in the field (including who has power and why) and the field's rules (Fligstein \& McAdam, 2011, p. 2). As SAF emphasises the need to consider collective actorsorganisations, social movements or even government 
systems - in addition to individual ones, it argues that collective actions work in conjunction with individual strategic actions to shape contestation and competition (Laamanen \& Skålén, 2015). As arenas of competition, fields have relatively flexible boundaries. They may be singular, or may be nested, and are characterised by actors' (1) diffused understandings regarding the rules of the field; and (2) ability to accumulate capital (Fligstein \& McAdam, 2011, pp. 3-6). Actors' competitiveness is determined by their ability to utilise their political capital.

SAF's view of contestation is actually parallel with Bourdieu's classical explanation of dominant dominators and dominated dominators (Wacquant, 1996); i.e., hyper-elites, as identified by Maclean and Harvey (2019). The terms refer to inter-actors' competition, where the most dominant actor (dominant dominators) may be present within a certain field, and consequently more dominated actors (dominated dominators) may exist in this field. According to Bourdieu, there are two types of political capital: that acquired by individuals and that acquired through delegation (Bourdieu \& Robinson, 1985; Kauppi, 2003). Individual political capital is produced through either "slow accumulation...or action in a situation of institutional void and crisis," reflecting the Weberian idea of charismatic legitimacy. Meanwhile, the political capital acquired through delegation is accumulated through institutions (Kauppi, 2003, pp. 779-780).

Competition with these fields, subfields and subsubfields will be understood through a competition of (1) the basis of elitisation, including formalisation, bureaucratisation and reputation; (2) the character of competition (i.e., the degree of openness); (3) level of competitiveness (i.e., high or low); (4) elitisation (i.e., production or stagnation of elites); and (5) elite formation (i.e., plural or monolithic).

\section{State Regulation of Civil Society}

This article aims to understand the situation through which one field influences the dynamics of another. In this case, we are focusing on the implications of state regulations on elitisation process.

The state is a stronger field than civil society, political society and economic society. It is "a kind of grand social organiser that constantly exercises a formative action of durable dispositions...it imposes fundamental principles of classification on everybody" (Kauppi, 2003, p. 781). As such, the State has the capacity to influences the rules of the game used by CSOs and other organisations.

Studies on the State, regulations and CSOs are not new to social science. However, we have been unable to find any articles that discuss the implications of state regulations on CSOs' elitisation processes. A study by Bloodgood, Tremblay-Boire, and Prakash (2014), for example, focused on how the nature of regime affects the way states regulate CSOs. They argued that macroinstitutional arrangements of representation crucially affect national styles of CSO regulation (2014, p. 716). State corporatists, who understand CSOs as obstacles to their regime, tend to limit their freedoms. Eldridge (1996), meanwhile, argued that the identification of Pancasila as a singular ideology through State regulation was an instrument used by the Soeharto regime to control CSOs in Indonesia. Conversely, pluralistic states that see CSOs as 'substitutes for formal communication channels' emphasise collaborative governance networks, prioritising policy priorities over organisational structures (Bassarab, Clark, Santo, \& Palmer, 2019, p. 32). A study by Lay (2017), for instance, showed how Indonesia's political reform has created more democratic space for CSOs to engage in policymaking.

A study by Antlöv, Ibrahim, and van Tuijl (2006) emphasised the negative impacts of state regulations on CSOs, where structural differentiation and functional specialisation provides space for power abuse. Several studies have emphasised the motivation of state regulations. The State's inclination to control CSOs through tight administration is aimed to limit these organisations' latitude, as in the case of Cambodia (McCarthy \& Un, 2017). The same logic applies to Jordan, where state regulation has been used to preserve the depoliticisation of women CSOs (Ferguson, 2017). Meanwhile, in Ethiopia, control has been exercised through the implementation of good governance principles, especially transparency and accountability (Yeshanew, 2012). Another study demonstrated how, in the UK, regulations have provided local NGOs with the political space to become involved in policy implementation (Lewis, 2008).

Plakhotnikova and Kurbanova (2008) use Kyrgyzstan to examine civil society transformation, state-building, and its implications for CSO leaders. Initially, leaders emerged spontaneously, impulsively and situationally but became organised as civil society became increasingly institutionalised actors. Since then, CSO activities have been "primarily linked to a high level of professionalism, succession procedures, and institutional sustainability" (p. 27), with educated individuals and women becoming leaders and activists. Leadership is no longer charismatic, but rather rational and legal.

Moving beyond existing studies on state regulation of civil society, this article argues that state regulations have led to the formalisation and bureaucratisation of CSOs. Formalisation and bureaucratisation have two different implications. For emerging democracies such as Indonesia, formalisation and bureaucratisation create new spaces for inter-elite competition, thereby promoting elite pluralism. This occurs when CSO elites orient themselves towards creating new subfields and entering said fields to maintain their elite status. Meanwhile, for states with shrinking civic space such as Cambodia, formalisation and bureaucratisation can narrow and even close spaces for inter-elite competition. Referring to the arguments of Knoke (1993) and Hoffman-Lange (2018), that elites may be identified through their position and reputation, this article argues that the formalisation and bureaucratisation of CSOs through state regulations can 
create new spaces for CSOs while simultaneously limiting the availability of spaces in non-prioritised sectors (see Figure 1).

\subsection{The Indonesian Case}

In Indonesia, the main instrument used to regulate CSOs and mitigate foreign influences is the Civil Society Organisation Law (Government of the Republic of Indonesia, 1985), which was passed by the authoritarian Soeharto regime (Detik, 2007; Eldridge, 1996). Since political reform in 1998, CSO activists have sought to transform State control. These demands have been positively received by post-reform regimes, and both CSOs and government agents have used legal instruments to ensure access to state resources, guarantee freedom of association and improve public participation.

This has been realised, for example, through the ratification of Law No. 12 of 2011 (Government of the Republic of Indonesia, 2011a), which requires the general public to be involved in the drafting of all laws. This has provided a legal means for civil society elites to become involved in the policymaking process. Since the passage of this law, CSO regulations have become increasingly diverse and detailed. For example, since its 2013 and 2017 revisions, the Civil Society Organisation Law (Government of the Republic of Indonesia, 2013, 2017) has allowed CSOs to exist as associations, foundations or without any legal status whatsoever. All CSOs, however, are required to have their own institutional structures and mechanisms.

Several further laws have regulated CSOs in more detail. The Foundation Law (Government of the Republic of Indonesia, 2001), for example, contained multiple articles that deal specifically with the institutional structure of foundations and mechanisms for filling them. Its replacement, Law No. 28 of 2004 (Government of the Republic of Indonesia, 2004) created new standards for CSOs, and thus affected their ability to access state resources and participate in policymaking activities. Today, Indonesia has many similar sectoral regulations; take, for example, Law No. 16 of 2011 (Government of the Republic of Indonesia, 2011b) regarding Legal Aid and the Presidential Regulation regarding the Procurement of Public Goods and Services, both of which regulate CSOs' access to funding. Regulation of the Minister of Villages, Development of Disadvantaged Regions and Transmigration No. 4 of 2015 (Ministry of Villages, Development of Disadvantaged Regions and Transmigration, 2015) regarding the Administration of Village-Owned Enterprises was drafted in the same spirit, enabling CSOs, community-based organisations (CBOs) and donors to work in conjunction with village-owned enterprises were approved by the village government and formalised through a memorandum of understanding. Under these regulations, which are intended to guarantee accountability and transparency, actors' formal positions within CSOs have become important.

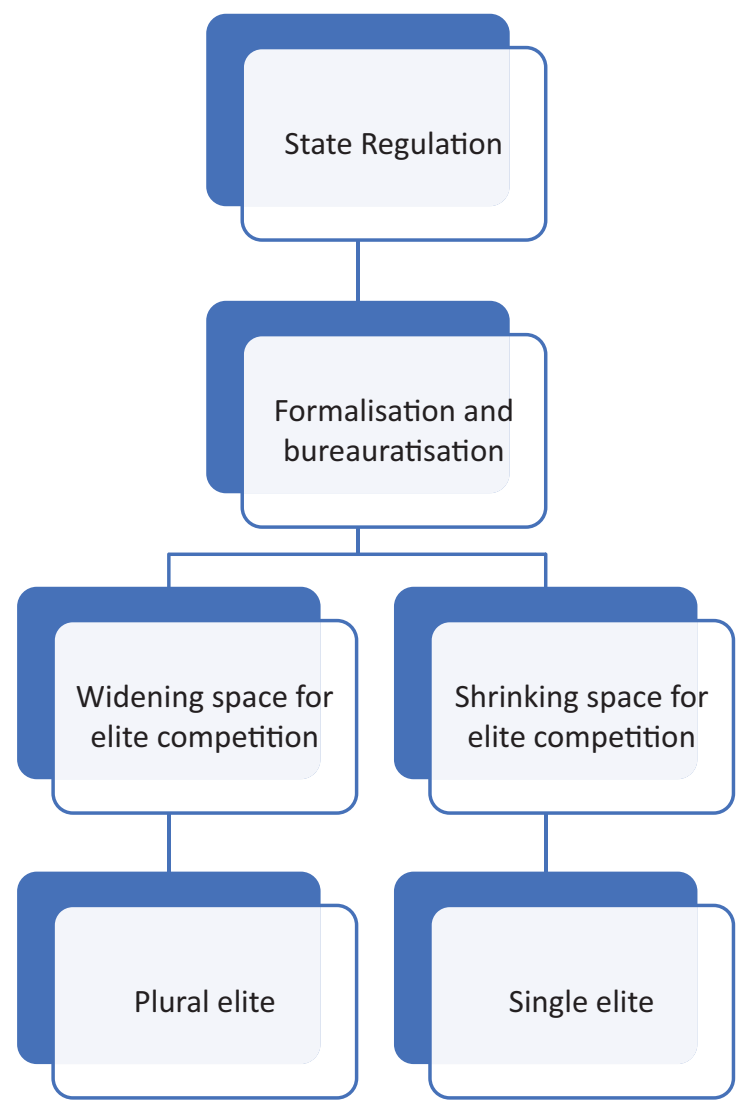

Figure 1. State regulations and elitisation. 
The internal rules of the game that regulate elite circulation in response to state regulations, which have always emphasised formal processes, have similar implications, insofar as actors' formal position is a central component of their legitimacy.

\subsection{The Cambodian Case}

The Cambodian government started to regulate the civil society sector after it passed the Law on Associations and Non-Governmental Organisations (LANGO) in 2010 and implemented it in August 2015 (Royal Government of Cambodia, 2015). The most frequently quoted justification for LANGO relates to the government's need to prevent foreign terrorist organisations (Karen \& Peter, 2015; Palatino, 2015) and to govern CSOs. According to officials at the Ministry of Interior, while there are thousands of NGOs operating in Cambodia, they are not being overseen by state regulations-which is particularly necessary as many organisations receive international funding.

Civil society actors have feared three aspects of LANGO's implementation: (1) Stringent requirements for registration as a legal entity to operate and receive funding, (2) regular reporting of activities and financial status (including amount and sources of funds) and (3) a vague provision that requires CSOs to be politically neutral (United Nations High Commissioner for Refugees, 2015; USAID, 2016). Registration is only a small part of LANGO. Interviews with officials of the Ministry of Interior who oversee the law's implementation suggested that its main aim is to create more transparency (particularly financial transparency) and accountability amongst CSOs who receive funding from international organisations and foreign governments. Not only does the ministry require activity and financial reports, but also bank account numbers, which enable the government to trace the source and amount of funding CSOs receive. Using such information, the government can potentially monitor and selectively target specific activities based on their leaders' political orientation as well as their funders. An additional concern from CSOs is the use of LANGO to close down NGOs that are critical of the government.

LANGO has been adopted together with broader political changes. Some observers note that the law's adoption suggests a change in the government's strategy to deal with civil society; it no longer relies on harassment and intimidation, but instead uses more complex mea- sures to threaten the sector (Un, 2019). One important aspect of this attempt to increase the regulation of CSOs is directly related to the government's claim that some civil society leaders and activists worked with the opposition party (the Cambodia National Rescue Party) to topple the government during and after the 2013 national election (Ministry of Foreign Affairs and International Cooperation, 2018).

Cambodia's civil society has entered a new era of uncertainty, with civic space being increasingly dictated by the State. This has affected elite production and circulation in a number of significant ways, as will be illustrated through a case study of Cambodia's agriculture sector.

\section{Elitisation in Civil Society}

Civil society, as well as the subfields and sub-subfields it contains, represents an arena for inter-elite competition as a part of elitisation. This will be demonstrated herein through the experiences of Indonesia and Cambodia (see Table 1).

\subsection{The Indonesian Case}

In the 1970s, agrarian reform became a central discourse in some notable universities in Indonesia. However, it transformed into a more organised movement following the establishment of the Consortium for Agrarian Reform in 1994. Over the years, the Consortium for Agrarian Reform has significantly influenced the establishment of CSOs and the production of civil society elites.

Agrarian reform was postponed by the Soeharto regime for 32 years because it was identified with communism. Nonetheless, activists revived discourses on agrarian reform in the early 1970 s using the AgroEconomic Survey, a government research institution under the Department of Agriculture (Saluang, 2019). G. Wiradi, a researcher-cum-activist who had been involved in the drafting of the Basic Agrarian Law (Government of the Republic of Indonesia, 1960) under President Sukarno, and Sajogyo, an academic who concealed his activism with agricultural research and programmes, were central in transforming agrarian reform from mere discourse into a subfield of civil society (Saluang, 2019). As agrarian issues became more complicated in the 1980s owing to the regime's repressive regulations, ideological activism (through student movements and CSOs' organisational engagement) became

Table 1. Comparison of the Indonesian and Cambodian cases.

\begin{tabular}{lll}
\hline Manner & Indonesia & Cambodia \\
\hline Formalisation and Bureaucratisation & High & High \\
Space for elite competition & Widening & Shrinking \\
Level of competitiveness & High & Low \\
Elitisation & Reproduction of elite & Stagnation of elite production \\
Elite formation & Pluralistic & Monolithic \\
\hline
\end{tabular}


more common, creating a triangle of intellectual-cumactivists, CSO leaders and student activists.

This alliance was marked by the establishment of the Consortium for Agrarian Reform - at the time an underground movement-in 1994 during a meeting of dozens of activists and intellectual elites from various CSOs (interview, D. Bachriadi, June 24, 2019). Consortium for Agrarian Reform represented the convergence of two specific interests, i.e., the interest of intellectual cumactivists to have agency and an outlet to materialise their ideas and the interest of CSO leaders and student activists to gain academic support for their movement.

In order to be recognised by the state as an organisation, since the very beginning, the Consortium for Agrarian Reform adapted its internal rules of the game to government regulations that required clear structures and forums for decision making as well as elite circulation mechanisms. Owing to internal regulations, this subfield promoted competition between formal civil society elites.

The dynamics of inter-elite competition within the Consortium for Agrarian Reform can be traced through the positioning and circulation of elites within its formal structure-its executive and legislative bodies, as well as its Expert Assembly. Internal Consortium for Agrarian Reform guidelines position the National Congress as a forum and mechanism for circulating elites and making decisions. Decision-making in the National Congress follows the principle of 'one man, one vote.' This does not hold true for the Expert Assembly, which is used by intellectuals and senior activists as a means of guiding discourse. Positions in the Expert Assembly are filled through appointment, while other bodies are populated through competitive mechanisms.

In Consortium for Agrarian Reform's early years, elite competition was not particularly prominent. This can be attributed to two main factors: (1) a relative lack of elites at a time when the number of CSOs was mushrooming and (2) a clear basis for elitisation, with individuals' elite status being derived from their activism, individual reputation, capacity to produce discourse and experience. It is not surprising that, between the First and Sixth National Congress, the leaders who occupied formal structural positions were campus activists who had been intensely involved in civil society movements and who had consistently produced and disseminated information on agrarian reform. Consortium for Agrarian Reform's lack of leadership in its early years, at a time when CSOs were mushrooming in number, meant that not all of its founding activists were involved in its internal competitions. Nonetheless, Consortium for Agrarian Reform has been treated as a collective property of CSO leaders from various sub-subfields.

Later developments resulted in the transformation of Consortium for Agrarian Reform's elitisation process. In the mid-2000s, as donor institutions increasingly emphasised managerial capacity, accountability and transparency, technocratic capacity became an important capital (Oxfam, 2020). At the same time, the State became an alternative source of funding and allowed CSOs to become involved in policymaking processes; in return, it expected certain technical standards to be met. This shift can be seen in the experiences of D. Kartika, the Secretary-General of Consortium for Agrarian Reform (2016-2021). After the Sixth National Congress (2013), when Kartika failed in her bid to become secretarygeneral, she descended to the grassroots and established legitimacy as an activist. Her appointment was also reinforced by the affirmative and inclusive policies imposed by international donor institutions. Ultimately, having accumulated resources outside the organisation itself as an activist, Kartika was made Secretary-General at the Seventh National Congress, receiving the majority vote (interview, D. Kartika, June 26, 2019). Her appointment as secretary-general, thus, cannot be separated from her ability to combine the diverse resources at her disposal.

Consortium for Agrarian Reform's first two National Congresses produced an organisational structure consisting of a chairman, an implementation body and a secretary-general. This structure was later simplified, consisting solely of the secretary-general and the supporting structure. Consequently, inter-elite competi-

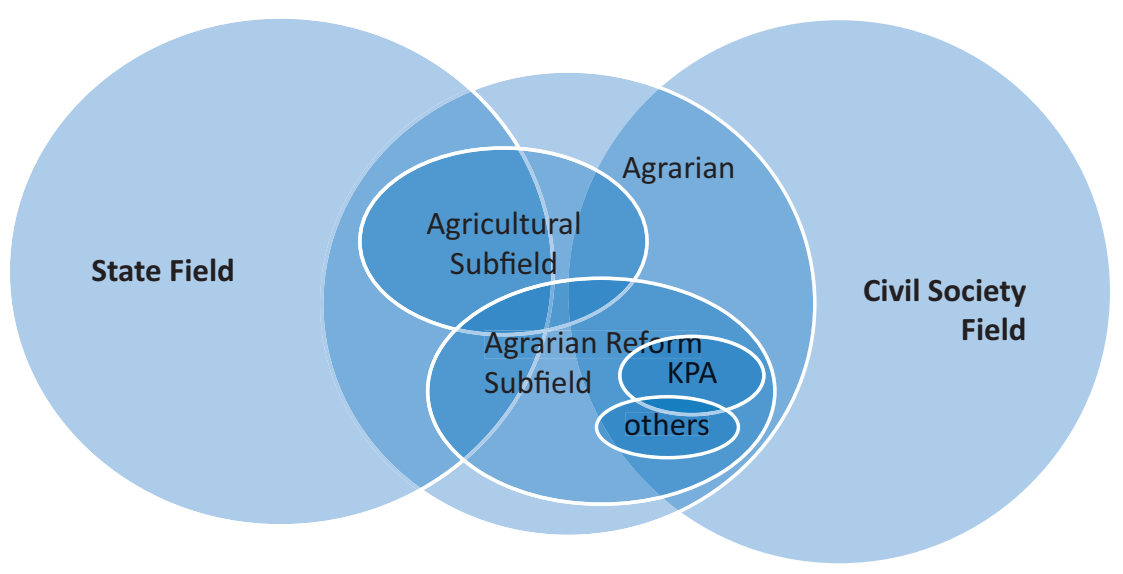

Figure 2. Connections among field, subfield, and sub-subfield of Indonesia case. 
tion became fiercer and elites were required to combine diverse resources to gain the support of National Congress participants.

This staunch internal competition drove Consortium for Agrarian Reform's leaders to seek new ways to persevere and be recognised as elites. They did this, first, by establishing new sub-subfields. This could occur through anticipatory measures, such as those used by Faryadi, who established the Alliance of Agrarian Reform Movements (Aliansi Gerakan Reforma Agraria) while still serving as the Consortium for Agrarian Reform's first secretary-general. Although the Consortium for Agrarian Reform intended this alliance to facilitate its creation of its own CBOs (Faryadi, 2016; Tanisa, 2003), over time it provided Faryadi with a sub-subfield in which he could exert power even after leaving the Consortium for Agrarian Reform. New sub-subfields could also be created in reaction to particular phenomena. For example, Zakaria, an intellectual-cum-activist who helped establish the Consortium for Agrarian Reform, was active outside the sub-subfield of the Consortium for Agrarian Reform; today, he chairs the Association for Village Renewal (Lingkar Pembaharuan Pedesaan dan Agraria), a CSO he established in 2002 that focuses on village and agrarian issues. He had also been involved in the drafting of the 2016 Village Law, which enabled CSOs and CBOs to become involved in village-level activities. The Consortium for Agrarian Reform's leaders used this law to establish Villages for Agrarian Reform (Desa Reforma Agraria), a grassroots project (interview, D. Kartika, June 26, 2019). Bachriadi established the Agrarian Resources Center in 2005, six years after finishing his term on the Implementation Body and shortly after leaving the Expert Assembly, while Rachman and other activists established the Sajogyo Institute for similar purposes in 2005.

The above phenomenon indicates the emergence and spread of elites, as reflected in the mushrooming of CSOs in recent decades. In 2001, Indonesia had only 429 active CSOs (PLOD, 2005); one decade later, it had at least 2,293 (Scanlon \& Alawiyah, 2015). This implies that organisational elites have become increasingly common and diverse. It means that inter-elite discrimination has promoted the diversification of CSO elites. This, in turns, has promoted checks and balances and has thus become a crucial part of democracy.

Since Indonesia began its political reform in 1998, Consortium for Agrarian Reform activists have been divided into two blocs, signifying a collective contestation. The first bloc views the State as enabling the realisation of agrarian reform, being the arena in which political decisions are made. The State is also important because of its significant symbolic power (interview, D. Kartika, June 26,2019$)$. The second bloc, meanwhile, argues that seizing such "political opportunities" would violate their principles as activists, who are expected to exist outside the State in order to provide checks and balances. For example, Bachriadi stated, "activists always talk about op- portunities...but movements are characterised by their ability to challenge [others]. Whether or not they have an open structure, opportunities, they will still challenge [others], as that is their driving principle" (interview, D. Bachriadi, June 24, 2019). In the context of emerging democracies such as Indonesia, this reflects EtzioniHalevy's (1993) argument that elite pluralism promotes checks and balances.

Second, elites have migrated to other fields, particularly the State. For example, Setiawan became involved in the State field while still serving as Consortium for Agrarian Reform's Secretary-General (2005-2009), having been asked to join the National Land Agency (Badan Pertanahan Nasional; interview, U. Setiawan, June 26, 2019). He chaired the Food Security Council at the Ministry of Agriculture before being asked to handle agrarian reform at the Presidential Staff Office. Other former Consortium for Agrarian Reform leaders who migrated to the State field included Rachmanbetter known as $\mathrm{Oji}-$ and Nurdin. A senior activist who was greatly respected by the Consortium for Agrarian Reform, Rachman, became part of President Jokowi's inner circle through his organisational network before ultimately working with the Jakarta Governor (interview, U. Setiawan, June 26, 2019).

Rahman was the first former Consortium for Agrarian Reform leader to join with Masduki (interview, D. Bahriadi, June 24, 2019), a civil society leader who helped found Indonesia Corruption Watch. Masduki had served on the National Ombudsman Commission. In 2014, after a stint on Jokowi's presidential campaign team, he became the Director of the Presidential Staff Office; today, he is Minister for Cooperatives and Small and Medium Enterprises. Nurdin, who is currently Chair of Consortium for Agrarian Reform's National Council, was also a member of the Presidential Staff Office. Similar trajectories were followed by other Consortium for Agrarian Reform leaders, including Wijayanto, who is now part of a special commission of the Jakarta Governor's Office. CSO activists' involvement in the State and civil society fields does not only necessitate complex networks amongst civil society elites, but also highlights the strong overlap between these fields. These fields, thus, are not sharply distinguished.

Third, elites established $\mathrm{CBOs}$ or remained active at the local (grassroots) level. Zakaria (interview, July 6, 2019) explained, “They don't disappear...their roles...become more diverse. Boy Fidro lived in a village, built schools, became a teacher...a principal...in Garut, Tasikmalaya, Ciamis." This practice is also illustrated by Agustiana, who represented the Pasundan Farmers' Association (Serikat Petani Pasundan) during Consortium for Agrarian Reform's establishment but remained active at the grassroots level (interview, D. Bachriadi, June 24, 2019; U. Setiawan, June 26, 2019). As such, local spaces have been maintained by the Consortium for Agrarian Reform elites, as these have provided them with a space for retaining their elite status. 


\subsection{The Cambodian Case}

Unlike the Consortium for Agrarian Reform, which is strongly characterised as a social movement, the agrarian subfield in Cambodia has involved agriculture and rural development-both key government priorities since the United Nations organised Cambodia's first national election in 1993 and the country became reintegrated into the region and the world. The establishment of the Farmer Center in 1997 followed international NGOs' successful implementation of agriculture and capacity development during the 1990s. The formal establishment of the Farmer Center also enabled the transfer of leadership from foreigners to Cambodians, as well as the transformation of international NGOs into Cambodian CSOs. As a national player in the agriculture and rural development field, the Farmer Center has become wellrespected, particularly for its ability to effectively provide training and extension services and mobilise capacity building for rural farmers and communities. The Farmer Center has been led by formal elites, representing a diverse group of high-profile individuals working in the civil society field and in large international organisations. One of the most recognised leaders today, Mr. Som, is known as a foreign-educated agriculture expert who introduced new approaches to agriculture as he increasingly accumulated social and cultural capital. His leadership of one foreign CSO's projects was followed by his appointment as the Farmer Center's first director in 2015. His success in obtaining donors' financial support and, through his personal networks within the Ministry of Agriculture, government political support resulted in the Farmer Center establishing close relations with rural farmers and formalising farmer associations in the country. The Farmer Center has grown from seven employees working in two villages in one commune in a province to a staggering 277 employees serving 7,200 villages in 1,050 (out of 1,640 ) communes in 22 of Cambodia's 24 provinces. In 2012, Mr. Som received the Ramon Magsaysay Award for his contribution to agriculture and poverty reduction.

Increased regulations, in conjunction with rural popular support for the work of the Farmer Center, prompted Mr. Som and his trusted network of NGO leaders to enter the political field. He played an important role in creating new sub-subfields by establishing the New Party in 2015, which provided Mr. Som, other CSO leaders, and farmer organisations an arena to explore opportunities in the political field. Despite Som's failed prime ministerial candidacy in 2018, the New Party received five commune council seats in four provinces. Given the number of seats contested $(11,500)$ and area covered, these results were insignificant; nonetheless, the New Party's showing is important within the context of Cambodia and its elections (Morgenbesser, 2019). The election of grassroots activists and organisational leaders such as Mr. Oun to commune government further strengthened his profile within farmer associations and Farmer Center.
Oun had become known as the president of the Farmer Association and as a member of the Farmer Center Board, having worked with donor agencies and gained popularity among grassroots members. Oun's ascendance from ordinary farmer to local political and agricultural elite reflect Mr. Som's and Farmer Center's ambition when it initiated the grassroots mobilisation and capacity building of rural farmers and their associations.

However, Som's focus on politics since 2016 has resulted in setbacks in Farmer Center's agricultural activities. As he focused on developing his party and political agenda, he left the CSO to new management. Mr. Som, as the leader of Farmer Center, became the 'most dominant actor' or 'hyper-elite' within the organisation's hierarchy owing to his loyalty to the regime and support for state priorities; this resulted in the stagnation of the elitisation process. Farmer Center's director since 2017, Malis, has thus experienced significant problems gaining formal recognition, including difficulty in registering the organisation's new management with the Ministry of the Interior and problems with human resources. Many senior staff have left Farmer Center, while international donor support has diminished (interview, Malis, May 2019).

Reflecting on Farmer Center's case, CSO regulation has had three major effects on elites in Cambodia. First, it has pushed CSO elites to forge a closer relationship with State elites, and this has taken place through investment in personal contacts. It has long been noted that one positive development during the 2000s was the localisation of leadership, with Cambodian nationals replacing foreigners in leadership positions (Öjendal \& Ou, 2015). This trend initially created opportunities to strengthen trust between CSO and State elites, and-as shown in the case study-enabled both to work closely. In the case of the Farmer Center, the personal relationship between Som and the Minister of Agriculture was important to the Farmer Center's success and enabled it to effectively provide input. CSO elites have had to move away from criticising the government to adopting a more engaging approach and assisting the government in carrying out its mission (see Henke, 2011). Such a phenomenon has also been seen in contemporary China, where CSOs have sought to create a 'win-win' situation (Fulda \& Song, 2012).

Second, CSO regulation has significantly constrained CSOs' ability and institutional capacity to carry out their mission, which has resulted in CSO elites moving to other fields. In the case of Farmer Center, the leadership team's engagement in politics by establishing a new political party that mobilised public support on the premise that CSOs are powerless and that drastic and large-scale change requires political power. Farmer Center, meanwhile, has faced significant institutional challenges in its relations with the government. This problem remained unsolved when interviews were conducted in May 2019. The organisation's change of leadership had yet to be recognised by the government, as its documentation 


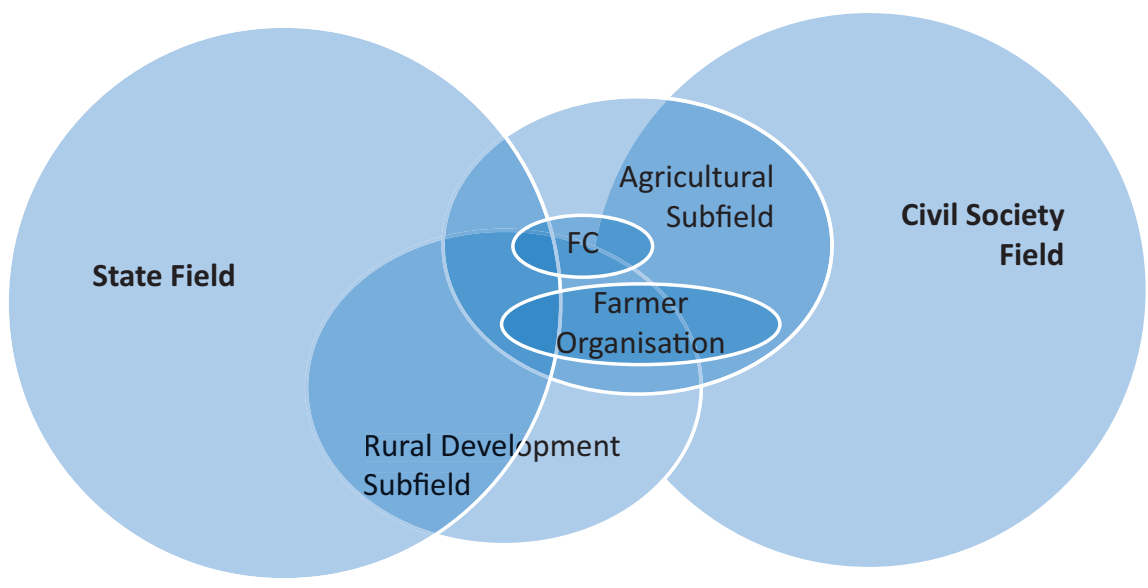

Figure 3. Links between field, subfield, and sub-subfield, Cambodia case.

was not accepted. Farmer Center has thus informally hired government officials to process this paperwork. This situation threatened its contract with the Ministry of Agriculture to provide training to farmers as well as its contract with the Ministry of Commerce to provide a special market for Farmer Center's farmers.

Third, pressure on CSO elites does not only come from the State, but also from international donors. Development partners have pressured CSOs to work within the narrow framework dictated by the government. From an international donor perspective, the law's implementation makes it difficult to provide funds to leaders who are not favoured by the government for fear of limited effectiveness. Donor funding for civil society has steadily declined in recent years; in 2016, for example, there was a $15 \%$ decrease in Official Development Assistance (USAID, 2016). Donors have responded to LANGO's implementation by selecting civil society and individual leaders that can work effectively on issues in which the government is interested. This shift in strategy is reflected in the political empowerment championed by the Farmer Center, whose funding has been significantly reduced due to its leadership's involvement in party politics. This has further limited the Farmer Center's ability to mobilise grassroot support and implement its activities with rural farmers. Furthermore, the provincial department of agriculture has discriminated against farmer organisations whose leaders are active in party politics; such farmers have been directly excluded from capacity building activities and faced distrust among community members.

This case study suggests that the impact of government regulations and dependence on foreign funding is likely to reinforce State-preferred civil society elites rather than local constituents, and to favour national elites over local elites as well as leaders with formal and technocratic knowledge over informal and political activism. Furthermore, it is highly likely that CSO elite must manage and combine different subfields in order to maintain their influence and elite status (see Figure 3).

\section{Conclusion}

The experiences of Indonesia and Cambodia show similarities as well as distinctions in the effects of CSO regulations. Both cases reveal the centrality of regulations, where states impose their fundamental principles of classification by drafting and implementing regulations to transform the character of civil societyincluding its fields, subfields, sub-subfields and elitisation processes. These cases also demonstrate that state regulations can fundamentally transform the process of elitisation through formalisation and bureaucratisation. Nonetheless, these two cases show a very different path. In Indonesia, State regulations have directly shifted the basis of legitimation, with formal institutional positions being used to legitimise elites' status. Formalisation and bureaucratisation have occurred as CSOs' collective capital have been converted to activists' individual capital, thereby intensifying contestation between elites. Elitisation occurs through formal mechanisms and is driven by bureaucratic logic, which has also promoted inter-elite discrimination as an integral part of the elitisation process. As a result, remaining elites have sought to find spaces wherein they can maintain their elite status. However, this has not resulted in stagnation. Rather, it has led to elite pluralism, providing a new basis for further democratic consolidation.

Meanwhile, in Cambodia regulation has limited the space available for contestation and created a monopoly that has stagnated the elitisation process. The case of Cambodia also shows that CSO regulation has significantly constrained CSOs' ability and institutional capacity to carry out their mission. CSO elites have thus moved to other fields, resulting in CSOs experiencing significant difficulty reproducing elites. Likewise, the effects of CSO regulations in Cambodian have not been direct. Instead, these regulations have been influenced by the political judgment of the regime and by CSO elites' ability to demonstrate support or even become part of the regime. Elites who have proven to be the most loyal to the regime have enjoyed privileges, being given a red-carpet 
to attain elite status. The case of Cambodia also confirms that personal relationships, such as that between Som and the Minister of Agriculture, were not only important to Farmer Center's success and ability to effectively provide input, but also explained the hyper-elite status achieved by certain actors. Regulations, therefore, have been used both as coercive and persuasive instruments--as stick and carrot--to uphold CSOs' loyalty to the regime. This model echoes Indonesia's authoritarian past under Soeharto when regulations were used to push CSO elites to establish closer relationships with State elites by investing in personal contacts.

Both cases also show that regulations have further implications. In Indonesia, on the one hand, they minimise activism's ability to mobilise civil society. On the other hand, they transform organisational processes from arenas for elite contestation into arenas for contesting resources qua resources. Administration and organisation are thus important material and symbolic capital for elitisation. This differs from the Cambodian case, where administration and organisation have functioned as arenas for State control. These case studies highlight the need to consider political contexts and regime characteristics when discussing the elitisation processes within CSOs.

\section{Acknowledgments}

The authors acknowledge support from Department of Political Science, Faculty of Social Sciences, Lund University, Sweden and Department of Politics and Government, Faculty of Social and Political Sciences, Universitas Gadjah Mada, Indonesia. We are grateful to all participants, individuals and organisations who provided valuable information and supported fieldwork in Indonesia and Cambodia. We also thank Desi Rahmawati, Arga Pribadi Imawan, Indah Surya Wardhani, Umi Lestari, and Samphors Korng who have been tirelessly working to make this manuscript available. We thank the editors of the thematic issue Håkan Johansson and Anders Uhlin, and anonymous reviewers for their valuable feedback on this article.

\section{Conflict of Interests}

The authors declare no conflict of interests.

\section{References}

Afiff, S. A., \& Rachman, N. F. (2019). Institutional activism: Seeking customary forest rights recognition from within the Indonesian state. The Asia Pacific Journal of Anthropology, 20(5), 453-470.

Antlöv, H., Ibrahim, R., \& van Tuijl, P. (2006). NGO governance and accountability in Indonesia: Challenges in a newly democratising country. In L. Jordan \& P. van Tujil (Eds.), NGO accountability: Politics, principles and innovations (pp. 147-163). London: Routledge.
Appe, S., Barragán, D., \& Telch, F. (2017). Civil society vocabularies and signaling value: Cases from Colombia and Ecuador. Administrative Theory \& Praxis, 39(2), 100-121.

Aspinall, E. (2005). Opposing Suharto: Compromise, resistance, and regime change in Indonesia. Palo Alto, CA: Stanford University Press.

Bassarab, K., Clark, J. K., Santo, R., \& Palmer, A. (2019). Finding our way to food democracy: Lessons from US food policy council governance. Politics and Governance, $7(4), 32-47$.

Bloodgood, E. A., Tremblay-Boire, J., \& Prakash, A. (2014). National styles of NGO regulation. Nonprofit and Voluntary Sector Quarterly, 43(4), 716-736.

Bourdieu, P. (1990). The logic of practice. Palo Alto, CA: Stanford University Press.

Bourdieu, P. (1996). The state nobility. Cambridge: Polity Press.

Bourdieu, P., \& Robinson, K. (1985). Delegation and political fetishism. Thesis Eleven, 11(1), 56-70.

Buehler, M. (2014). Elite competition and changing statesociety relations: Shari'a policymaking in Indonesia. In M. Ford \& T. Pepinsky (Eds.), Beyond oligarchy: Wealth, power, and contemporary Indonesian politics (pp. 157-175). Ithaca, NY: Cornell Southeast Asia Program Publication.

Case, W. F. (1996). Can the "halfway house" stand? Semidemocracy and elite theory in three Southeast Asian countries. Comparative Politics, 28(4), 437-464.

Eldridge, P. (1996). Development, democracy and non-government organisations in Indonesia. Asian Journal of Political Science, 4(1), 17-35.

Etzioni-Halevy, E. (1993). The elite connection. Cambridge: Polity Press.

Faryadi, E. (2016). Reformasi agraria, fondasi pertanian [Agrarian reform, agricultural foundation]. Syambadaba. Retrieved from http://syambadaba. blogspot.com/2016/09/masalah-pengalihan-fungsilahan.html

Ferguson, P. A. (2017). The state of Jordanian women's organisations five years beyond the Arab Spring. Politics and Governance, 5(2), 59-68.

Fligstein, N., \& McAdam, D. (2011). Toward a general theory of strategic action fields. Sociological Theory, 29(1), 1-26.

Fulda, A. L. Y., \& Song, Q. (2012). New strategies of civil society in China: A case sudy of the network governance approach. Journal of Contemporary China, 21(76), 675-693.

Government of the Republic of Indonesia. (1960). Law on basic agrarian (Law No. 5 of 1960). Jakarta: Government of the Republic of Indonesia.

Government of the Republic of Indonesia. (1985). Law on civil society organisation (Law No. 8 of 1985). Jakarta: Government of the Republic of Indonesia.

Government of the Republic of Indonesia. (2001). Law on foundation (Law No. 16 of 2001). Jakarta: Government of the Republic of Indonesia. 
Government of the Republic of Indonesia. (2004). Law on amendment to law number 16 of 2001 on foundation (Law No. 28 of 2004). Jakarta: Government of the Republic of Indonesia.

Government of the Republic of Indonesia. (2011a). Law on establishment of regulation (Law No. 12 of 2011). Government of the Republic of Indonesia. Jakarta: DPR.

Government of the Republic of Indonesia. (2011b). Law on legal aid (Law No. 16 of 2011). Jakarta: Government of the Republic of Indonesia.

Government of the Republic of Indonesia. (2013). Law on civil society organisation (Law No. 13 of 2013). Jakarta: Government of the Republic of Indonesia.

Government of the Republic of Indonesia. (2017). Law on enactment of government in leu of Law Number 2 of 2017 concerning amendments to Law Number 17 of 2013 on civil society organisation into law (Law No. 16 of 2017). Jakarta: Government of the Republic of Indonesia.

Henke, R. (2011). NGOs, people's movements, and natural resource management. In C. Hughes \& K. Un (Eds.), Cambodia's economic transformation (pp. 288-310). Copenhagen: NIAS Press.

Hoffman-Lange, U. (2018). Methods of elite identification. In H. Best \& J. Hihgley (Eds.), The Palgrave handbook of political elites (pp. 79-92). London: Palgrave Macmillan.

Kauppi, N. (2003). Bourdieu's political sociology and the politics of European integration. Theory and Society, 32(5), 775-789.

Knoke, D. (1993). Networks of elite structure and decision making. Sociological Methods \& Research, 22(1), 23-45.

Laamanen, M., \& Skålén, P. (2015). Collective-conflictual value co-creation: A strategic action field approach. Marketing Theory, 15(3), 381-400.

Lay, C. (2017). The emerging of new democratic space: CSOs and parliament in post-Soeharto Indonesia. PCD Journal, 5(1), 1-24.

Lewis, D. (2008). Crossing the boundaries between 'third sector' and state: Life-work histories from the Philippines, Bangladesh and the UK. Third World Quarterly, 29(1), 125-141.

Maclean, M., \& Harvey, C. (2019). Pierre Bourdieu and elites. In S. Clegg \& M. Pina e Cunha (Eds.), Management, organisations and contemporary social theory (pp. 98-114). London: Routledge.

McCarthy, S., \& Un, K. (2017). The evolution of rule of law in Cambodia. Democratization, 24(1), 100-118.

Migdal, J. S. (1988). Strong societies and weak states: State-society relations and state capabilities in The Third World. Princeton, NJ: Princeton University Press.

Ministry of Villages, Development of Disadvantaged Regions and Transmigration. (2015). Villages, development of disadvantaged regions and transmigration Minister regulation number 4 of 2015. Jakarta: Min- istry of Villages, Development of Disadvantaged Regions and Transmigration.

Ministry of Foreign Affairs and International Cooperation. (2018). Cambodia stability and development first. Phnom Penh: Ministry of Foreign Affairs and International Cooperation. Retrieved from https:// www.mfaic.gov.kh/wp-content/uploads/2018/02/ 4T2-Stability-12-February-2018.pdf

Morgenbesser, L. (2019). Cambodia's transition to hegemonic authoritarianism. Journal of Democracy, 30(1), 158-171.

Karen, K., \& Peter, Z. (2015, July 9). Opposition walks out of NGO law workshop. The Diplomat. Retrieved from https://english.cambodiadaily.com/news/opposition -walks-out-of-ngo-law-workshop-87637

Öjendal, J., \& Ou, S. (2015). The 'local turn' saving liberal peacebuilding? Unpacking virtual peace in Cambodia. Third World Quarterly, 36(5), 929-949.

Oxfam. (2020). Development: Raising women's voices, realizing rights, building resilience in Indonesia. Oxfam. Retrieved from https://oxfamblogs.org/ indonesia/development

Palatino, M. (2015, July 17). Does Cambodia really need a new NGO Law? The Diplomat. Retrieved from http://thediplomat.com/2015/07/does-cambodiareally-need-a-new-ngo-law

Detik. (2007). Perlu UU sebagai dasar hukum audit LSM [A law is needed as legal basis for CSO audit]. Detik. Retrieved from https://news.detik.com/berita/d813778/perlu-uu-sebagai-dasar-hukum-audit-Ism-

Plakhotnikova, G., \& Kurbanova, A. (2008). Profile of an NGO leader. In J. Couper (Ed.), Kyrgyzstan today: Policy briefs on civil society, migration, Islam and corruption (pp. 25-30). Bishkek: AUCA.

PLOD. (2005). Keterlibatan publik dalam desentralisasi tata pemerintahan [Public's involvement in governance decentralisation]. Yogyakarta: Gadjah Mada University.

Robison, R., \& Hadis, V. (2004). Reorganising power in Indonesia: The politics of oligarchy in an age of markets. London: Routledge.

Royal Government of Cambodia. (2015). Law on associations and non-governmental organizations. Phnom Penh: Royal Government of Cambodia.

Saluang, S. (2019). GWR Jali Merah: Dari berbagai tuturan biografis Gunawan Wiradi [GWR Jali Merah: Based upon Gunawan Wiradi's biographical utterances]. Jakarta: Pustaka Obor Indonesia.

Scanlon, M. M., \& Alawiyah, T. (2015). The NGO sector in Indonesia: Context, concepts, and an updated profile. Barton: Australian Department of Foreign Affairs and Trade. Retrieved from https://www. ksi-indonesia.org/assets/uploads/original/2020/02/ ksi-1580493585.pdf

Sidel, J. T. (2005). Bossism and democracy in the Philippines, Thailand, and Indonesia: Towards an alternative framework for the study of 'local strongmen.' In J. Harris; K. Stokke, \& O. Törnquist (Eds.), Politicising 
democracy (pp. 51-74). London: Palgrave Macmillan. Swartz, D. (1997). Culture and power: The sociology of Pierre Bourdieu. Chicago, IL: University of Chicago Press.

Tanisa. (2003). 9 hari lagi munas KPA: refleksi perjalanan [Nine days to KPA's national meeting: a reflection]. KPA. Retrieved from http://kpa.or.id/media/baca/ liputan\%20khusus/389/9_HARI_LAGI_MUNAS_ KPA:_Refleksi_Perjalanan_3_

Uhlin, A. (1997). Indonesia and the 'Third Wave' of democratisation: The Indonesian pro-democracy movement in a changing world. Richmond: Curzon Press.

Un, K. (2019). Cambodia: Return to authoritarianism. Cambridge: Cambridge University Press.

United Nations High Commissioner for Refugees. (2015, August 4). A human rights analysis or the law on associations and non-governmental organisations.
Geneva: United Nations High Commissioner for Refugees. Retrieved from https://cambodia.ohchr. org/ cambodiaohchr/sites/default/files/OHCHR_ analysis_of_5th_LANGO_Eng.pdf

USAID. (2016). CSO sustainability index for Asia. Washington, DC: USAID. Retrieved from https:// www.usaid.gov/sites/default/files/documents/ 1866/2016-Asia-CSOSI-Report-v4-508.pdf

Wacquant, L. (1996). Foreword. In P. Bourdieu (Ed.), The state nobility: Elite schools in the field of power ( $\mathrm{pp}$. ix-xxii). Cambridge: Polity Press.

Weller, R. P. (Ed.). (2004). Civil life, globalisation and political change in Asia: Organising between family and state (Vol. 10). London: Routledge.

Yeshanew, S. A. (2012). CSO law in Ethiopia: Considering its constraints and consequences. Journal of Civil Society, 8(4), 369-384.

\section{About the Authors}

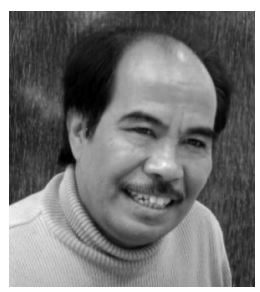

Cornelis Lay is Professor of Politics and Government at Universitas Gadjah Mada, Editor in Chief of Power, Conflict, and Democracy (PCD) Journal and Head of the Research Centre for Politics and Government (PolGov) at the Department of Politics and Government, Faculty of Social and Political Sciences, Universitas Gadjah Mada. His main study includes political linkages, civil society, political party, democratic decentralisation and local politics, and border governance.

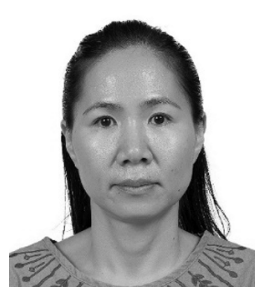

Netra Eng is Research Director at the Cambodia Development Resource Institute (CDRI) in Phnom Penh. She has been researching and writing about political economy of institutional reforms, decentralisation and local leadership in Cambodia. She is currently managing a number of research projects, one of which examines the impact of Cambodia's millennial generation of society and politics. 